\section{Questión}

Periodismo / Comunicación ISSN 1669-6581
- Av. $44 \mathrm{~N}^{\circ} 676,1^{\circ}$ piso

CP 1900 - La Plata - Argentina

(i) www.perio.unlp.edu.ar/question

Coronados de gloria

Martín Marcos Martinic Magan

https://doi.org/10.24215/16696581e405

\title{
Coronados de gloria I
}

\section{Crowned with glory I}

Martín Marcos Martinic Magan

Docente, desde hace mucho: Periodista, aveces, Escritor, humanamente siempre. O la versión oficial: Docente de la Cátedra de Comunicación y Cultura nivel secundario y del Taller de Realización Audiovisual nivel terciario. Lic. en Comunicación Social-FPyCS.UNLP. Coordinador del Archivo de la Palabra-Radio

\section{Coronados de gloria I}

\section{Ahora}

en este ahora

de hora sin reloj.

Ahora

que tantos estamos

buscando en qué caricias

trasladar

tanta quietud

de abrazo inquebrantable.

\section{Ahora}

que mi suegra

me pasa una cebolla

por la tapia del WhatsApp.

\section{Ahora}

en que llevamos

harina y saludos 
a los viejitos del fondo.

Los colmillos parecen

detenidos

y sólo queda

el dulce deseo de estar vivos.

De matar la muerte,

tan injusta como tantas

que dejaste pasar.

De celebrar el cielo

y los balcones.

De cobijar al otro

y a uno mismo.

De tornar con gracia

la desgracia

de transitar sin pies

todos los besos.

Sumo lo que puedo

como cada quien

que anda sin andar

escudriñando entre sus cosas

lo que haga puente.

Sumo inexacto

a la manada de lobos dulces

marchando hacia el sol,

con los viejos delante,

para que no quede nadie

en el camino.

Sumo este color

al cuadro exquisito

del cadáver de certezas

que supimos conseguir. 
Un tono pastel

de palabra impalpable.

Una gama de esdrújulas

minúsculas y graves.

Unas letritas

al tiempo sin tiempo

de los microcosmos

cantando lo ausente.

Una dudosa destreza

de jugar con puntos

en el espacio

dónde el silencio cure.

Si hasta acá llegaste

te he robado tiempo y

te he ofrendado

nada, algo,

todo lo que tenemos

para dar vuelta al mundo

y lo que

ahora

es

esta incierta hora del ocaso

se vuelva Alba.

\section{Coronados de Gloria II}

Mi compañero me dice que algo dijo

Perón

de una pandemia yanquimarxista.

Y se desvive de Barrio

arropando con guisos la desnudez de siempre.

Y me dice de algún rock

que nos vuele la tapa de los diarios 
goteadores de tinta roja

y muertos amarillos

Intercalando descuentos

en fin de temporada.

La tele me dice de quedarme en casa

Primetime.

Que done las ultimas neuronas

a la justa causa de coca cola

ahogando colombianos,

secando pueblos hindúes.

A la aséptica cruzada de lizoform

asesinando lo que no ves

desde la torre de cristal plasma

en donde me han coronado.

Mi amiga me dice de bailar

Tango

con un tutorial japonés o uruguayo

de zapatos subtitulados.

O hacer un curso de mercadotecnia

online o cine clásico italiano.

Que de la cuarentena debemos

salir profesionales de algo

para enrostrarle a los nietos

que nadie tendrá.

La empresa me dice de aportar

Miedo

a perder el trabajo que gana mis panes

y sostener el empate 
en la ecuación de la plusvalía.

Y mantener la distancia

de los otros, de mi mismo.

$Y$ gimotear a solas mordiendo

el pliegue del codo,

en donde guardo la angustia.

Mi vecino me dice de cortar

El pasto

que afea la fachada hacia el Norte.

$Y$ acaricia el lomo de su perro francés

mientras corre en círculos

alrededor de nada.

Persiguiendo la huida

del susurro huesudo

que muta de nombre

y apellida la muerte.

La bolsa me dice que compre acciones

A la baja

de esas aventuras de bronce

Que hasta ayer nomas

servían para volar a Bali

o a algunos palestinos

que lamentan los muros

y roban su tierra escondida

bajo la lengua.

Mi hermana me dice de escribir

Algo.

De esas cosas que salvan al mundo, 
aunque no se entere.

Poesía, palabritas subidas

unas sobre otras.

Estilizadas en la hoja

en los ojos

nublados por un ventisquero

trumbando tras el parpado.

Que bramido sordo el de las letritas

aunadas

en Dominicana, Brasil, la esquina 19.

Jactancia del tiempo y de la burguesía

allí donde el surco se inunda de tos

de conquista, de fiebre, de glifosato.

Que soberbia dulce y temblorosa

Hasta que llegue un pobre

científico explotado

y nos vacune de impunidad

para volver a ser el numero

que siempre cargamos

en el cajero automático. 